\title{
内頸静脈の再建を要した虎外傷例
}

\author{
大島＼cjkstart収・藤田 豪紀・野村研一郎・高橋 光明
}

\section{A Case of Tiger Bite Injury with Unilateral Internal Jugular Vein Reconsruction}

\author{
Osamu Oshima, Taketoshi Fujita, Kenichiro Nomura, Mitsuaki Takahashi \\ (Asahikawa Red Cross Hospital)
}

\begin{abstract}
We reported a very rare case of tiger bite injury. The patient was a 57 -year-old male who was a keeper at Asahiyama zoological park in Asahikawa city. He was attacked by an Amur tiger which seriously injured upper half of his body, including intracranial trauma. We performed an operation to save his life. There was severe bleeding from the cervical wound because the left internal jugular vein was severed, therefore, it was clamped and occluded with ligatures. We treated his many wounds, but the intracranial bleeding was not relieved. We considered that ascending intracranial pressure by occlusion of the left internal jugular vein caused the bleeding. Left internal jugular vein reconstruction was performed by neurosurgeons. They used an artificial graft initillay, and then used the greater saphenous vein as a graft. We considered the patient's left internal vein as the dominant side.
\end{abstract}

Key words : tiger bite injury, jugular vein reconstruction, intracranial trauma, dominant side

はじめに

頭頸部外科領域，特に頭頸部悪性腫瘍手術において問 題となるが，内頸静脈処理に対する考え方として，両側 の内頸静脈を切除もしくは結紮してしまうとまれに失明 などの合併症 ${ }^{1)}$ も報告されており，可能な限り一側の保 存を試みるのが一般的である。今回われわれは，まれな 外傷機転で頭蓋内の外傷を合併した頸部外傷の止血のた め一側の内頸静脈を結紮したところ, 頭蓋内からの出血 が制御不能となり，そのため結紮した内頸静脈の再建を 要した症例を経験したので報告する.

\section{症例}

症例 : 57 歳, 男性.

職業 :

既往歴, 家族歴：特記事項なし。

現病歴: 平成 15 年 2 月 13 日午後, 北海道旭川市立旭 山動物園猛獣館で作業中, 同園で飼育されているアムー
ル虎に襲われた. 14 時 30 分頃発見され，15 時に救急車 の要請あり.救急隊および動物園職員等により救出され, 15 時 50 分頃当院救急外来に到着した.

現症および検查所見：到着時意識 JCS I- $1 \sim 2$, 体温 $30.4^{\circ} \mathrm{C}$, 血圧 $105 / 78 \mathrm{mmHg}$, 白血球 $19000 / \mu 1, \mathrm{Hb} 11.7 \mathrm{~g} /$ $\mathrm{dl}, \mathrm{pH} 7.017, \mathrm{BE}-19.9 \mathrm{mmol} / \mathrm{L}$. 出血に伴らショック状 態で，低体温，代謝性アシドーシスの状態であった。

頭部から上肢にかけて多数の裂傷を認めた. 左耳介は 頭部から頸部への裂傷に連続して複雑に切れており, 外 耳道は軟骨部で断裂していた（図 1)。後頭部頭皮は，頭 蓋骨から皮弁状に遊離していた。両側耳下腺が露出して いたが，顔面神経麻痺は明らかではなかった．特に側頭 部には虎犬歯が頭蓋骨を貫通したと思われる骨欠損が認 められた。 神経学的には特に異常所見は認められなかっ た. 当院到着時には，頭頸部㧍よび上肢の多数の創部か らの出血はショック状態のため一時的に止まっていた. 画像所見 (図 2)：頭部単純写真側面 (RL) 像では頭蓋 


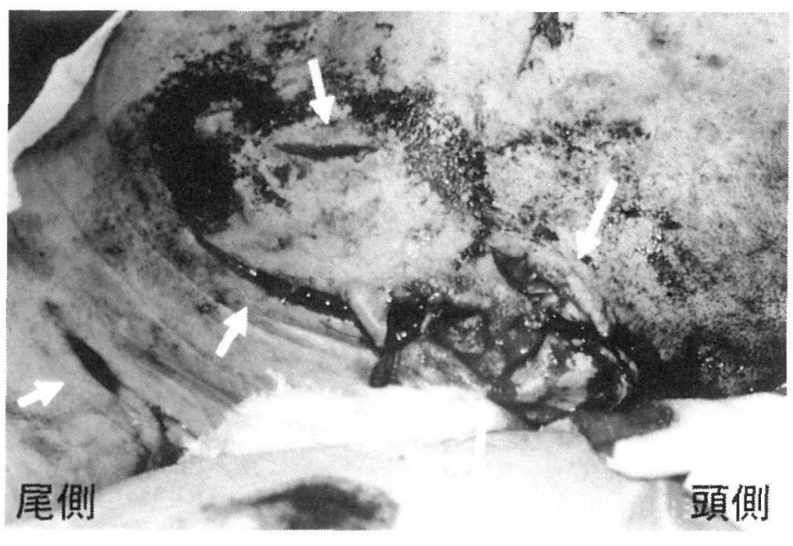

図 1 当院救急外来搬入時所見（仰臥位） 左側頸部から左耳介および左側頭部にかけての挫裂創。 創はさらに後頭部へと連続している.

骨に透見像がみられ，虎犬歯の頭蓋骨貫通が示唆された。 頭部 CT 検査では, 貫通部に一致して骨欠損および脳出 血，脳挫傷が認められた。

経過：検查終了後, 救命手術が行われた。全身麻酔が 導入され，薬剤や輸血等により循環動態がやや改善して くると，まず左頸部創より大量に出血があった，左顎二 腹筋後腹の高さよりやや上方で, 左内頸静脈がほぼ全周 性に裂けて出血していることが判明した。止血のため,

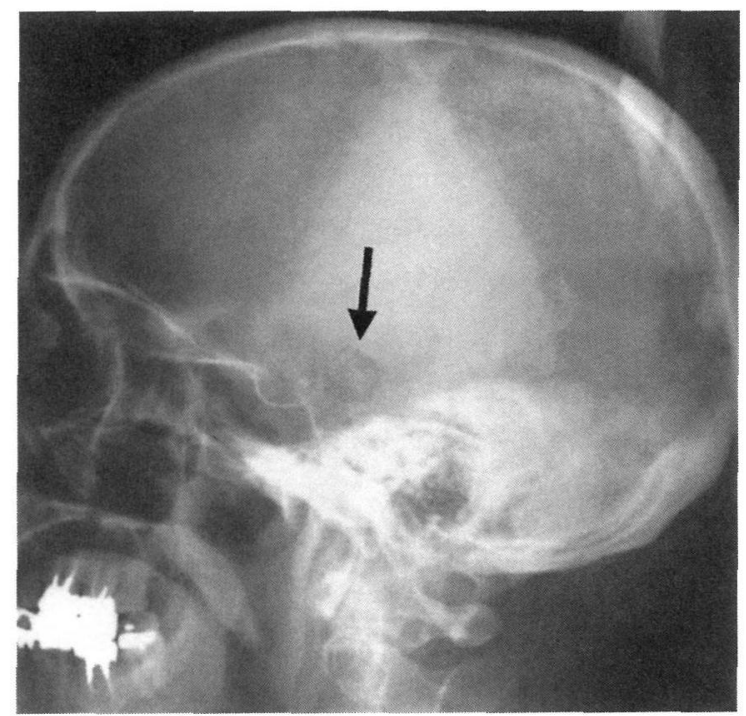

頭部単純 RL
その裂傷部の上下を 2-0 絹糸で結紮し切断した。しかし それと同時に全身の創部より出血したため，まず脳神経 外科医および整形外科医により創洗浄，デブリードメン 卜，縫合および止血操作が行われた。しかしながら虎犬 歯の頭蓋骨貫通部を通して頭蓋内からの出血が持続し， 脳浮腫む出現していた (図 3). 脳神経外科医汃ら左内頸 静脈の結枈に伴う血行遮断により頭蓋内の静脈圧が艺進 し, そのための出血と判断が下された。緊急避難的にゴ アテックス製人工血管にて左内頸静脈を上下の断端にて 端々吻合し, 血行を再建したところ, 出血, 脳浮腫は徐々 に改善してきた。しかしながら，人工血管の閉塞を考慮 し, 左側下肢より大伏在静脈を採取, 上端は内頸静脈に 端側吻合し，下端は左顔面静脈泣端側吻合された (図 4). 脳神経外科医による手術が終了した後, 当科で顔面, 頸 部の裂傷の創洗浄, デブリードメント，縫合を施行した。 特に左耳介は，軟骨を修復しながら縫合したが，外耳道 に関しては, 鼓膜を確認した後, 外耳道に抗生剤軟膏付 きガーゼを挿入して，可及的に修復し手術を終了した。 手術後, 集中治療室で管理された。内頸静脈の血行再建 が時間的に間に合っているか否かが問題となったが，術 後特に神経学的異常所見はなく, ほかの合併症を併発す ることなく順調に経過し，2月18日には一般病棟に移り， 同年 4 月 30 日に退院となった (図 5)。現在当科では, 外
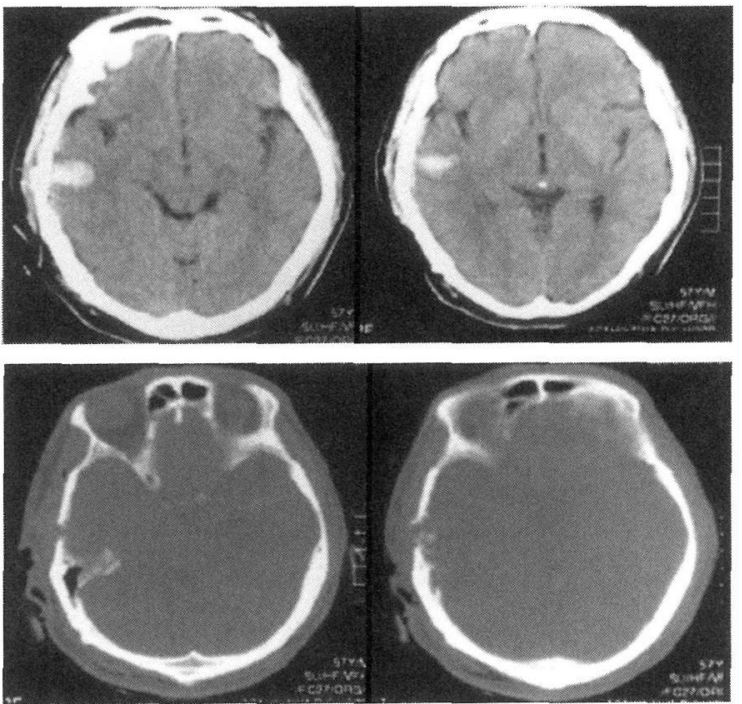

頭部 CT

図 2 画像所見

左に頭部側面像，右に頭部 CT 所見を示す。虎犬歯が頭蓋骨を貫通し，頭蓋内に出血が認められる（矢印）。 


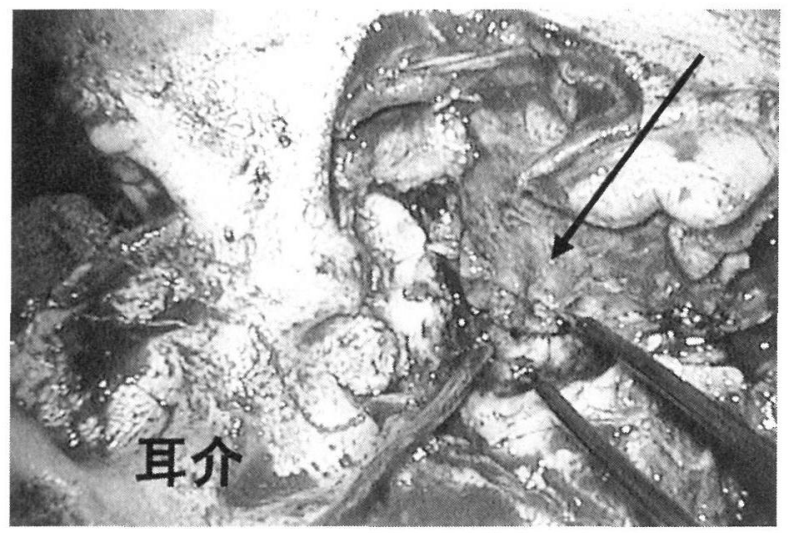

図 3 手術所見 1

頭蓋骨貫通の骨を一部鉗除し, 頭盍内を確認. 矢印は脳 実質および硬膜を示す。

耳道の状態を外来にて経過観察中である.

\section{考察}

内頸静脈損傷時の対応として, 縫合で対処できるので あればそれでよいし, 縫合が困難であれば静脈保存の方
針を断念して内頸静脈を合併切除すればよい，まして根 治的頸部郭清術では内頸静脈を合併切除するので全く問 題ないと考えられる. しかし, 両側の内頸静脈を結紮し てしまうと, 術後まれではあるが失明などの重大な合併 症も報告1)されており, 可能な限り一側の保存を試みる ことになる2).今回のわれわれの症例では, 一側の内頸 静脈を止血のために結紫切断したところ, 頭蓋内圧充進 を促し, 頭蓋内の出血が治まらない原因となったと考光 られ, 重篤な合併症を引き起こす可能性があると脳神経 外科医に指摘を受けた。結森側の内頸静脈の再建が時間 的に間に合い, 特に問題なかったが, この結果から, ま ず一側の内頸静脈の切断が頭蓋内の血行に重大な影響が あることが示唆された。

内頸静脈が単独で処理されることは害地臨床において はまれであり, 多くは頭頸部悪性腫愓における頸部郭清 手術に関連する報告である，根治的頸部郭清術において は種々の術後の脳合併症が報告されている3) 5). この脳 合併症は片側または両側の内頸静脈を結紮切除すること により静脈系の脳循環が阻害されることによる頭蓋内圧 克進がかかわっていると推測される。しかし臨床におい
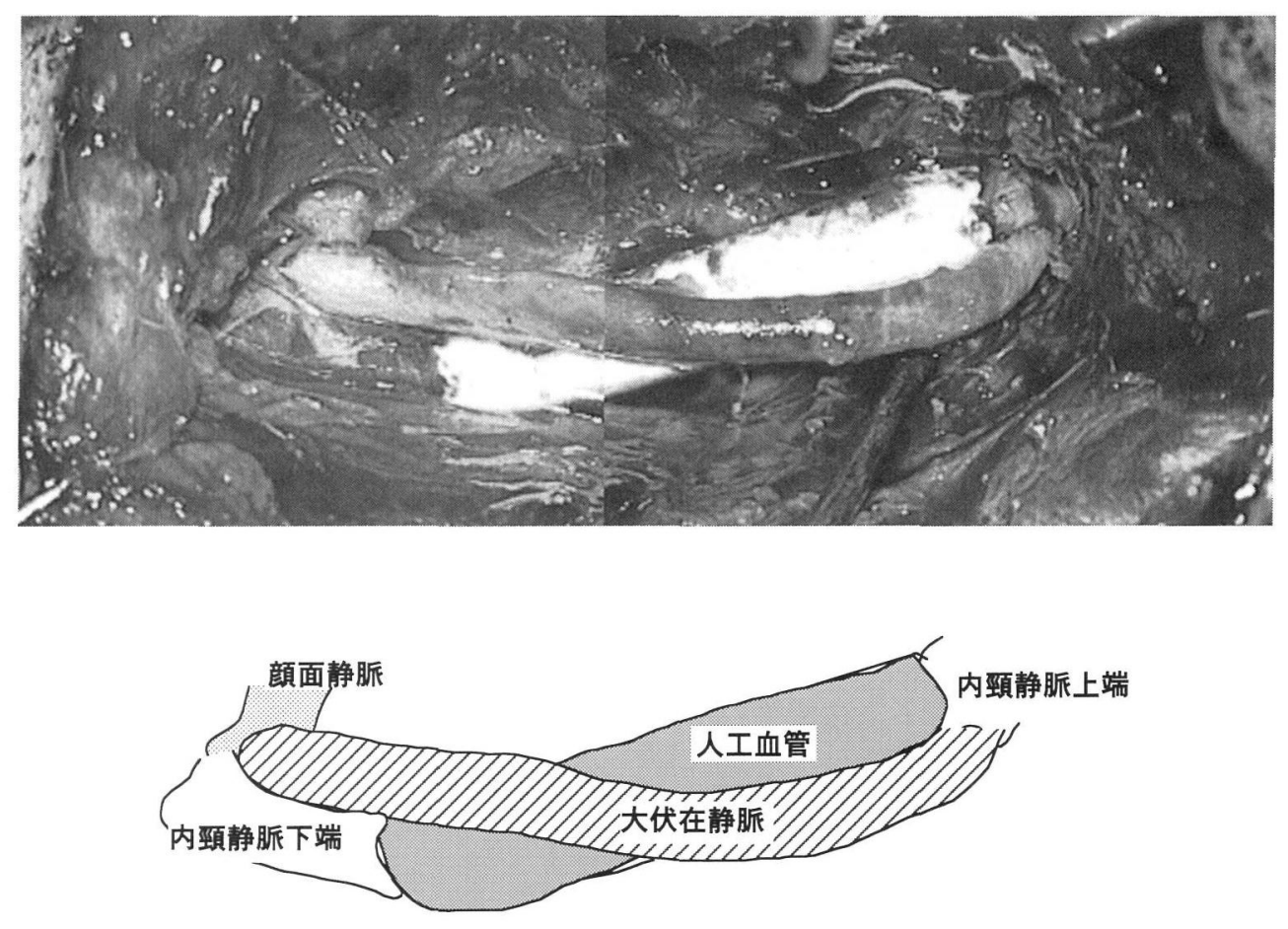

図 4 手術所見 2

左側内頸静脈の再建. 上段は, 手術ビデオ画像より左内頸静脈再建の状態を合成した。下段にはそのシェーマを示す. 

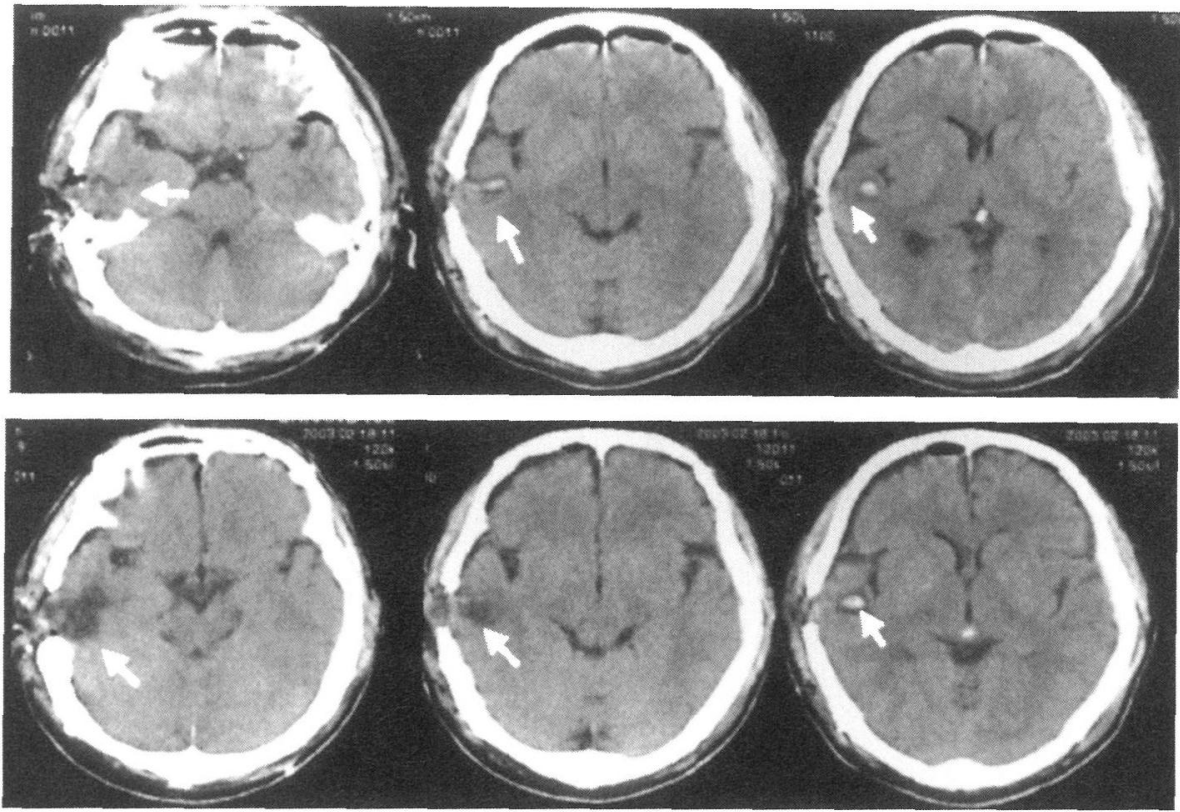

図 5 術後頭部 CT 所見

上段に術直後，下段に術後 4 日目の頭部 CT 所見を示す．術前に比べ特に血腫の増大はなく，脳浮腫もほとんど認めない.

ては, 頭盖内圧を直接モニターすることは侵襲が大きい。 山崎ら ${ }^{6)}$ は, 頸部郭清手術症例に対し硬膜外腔圧が頭盍 内圧をよく反映するとして術中術後モ二ターし，指標と している。その報告によれば，8例の片側性頸部郭清術 において硬膜外腔圧が全例で上昇し，平均 $15 \mathrm{mmHg}$ (最

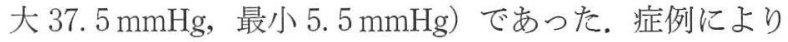
一様ではなかった理由として，個人的な側副血行路の発 達や内頸静脈径の左右差（例えば太い方を切除すると上 昇は著しいなど）が関与していると考えられた。 内頸静 脈の左右差に関し，Lichtenstein $ら^{7)}$ は ICU 入室患者 80 人に対し超音波検查で検討したところ, 内頸静脈の左右 差が明らかなのは $62.5 \%$ で, そのらちの $68 \%$ が右側優位 たったと報告している. Cormio ら ${ }^{8)}$ は 17 人の頭部外傷 患者で調查したところ，65\%で右側の内頸静脈の方が大

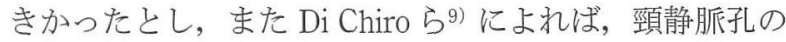
大きさの比較では右側が大きいのは $62 \%$ ，小さいのは $32.5 \%$ ，同等で $5.5 \%$ ，Navsa ら ${ }^{10)}$ の報告では 93 例の頭 蓋底解剖により有意差をもって右側頸静脈孔が大きかっ たとしている。さらに頭盍内の硬膜静脈洞に関して,

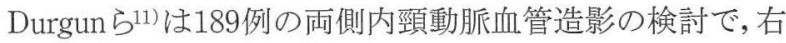
側優位 $43.9 \%$, 左側優位 $18.5 \%$, 同等である $37.6 \%$, 右 側のみ $2.1 \%$ ，左側のみ $0.53 \%$ と頭圔内においても右側 がやや優位とされる。また根治的頸部郭清術後の対側内
頸静脈の血流速度をみた報告では，右側郭清術施行例が $110 \%$ 増加に対し, 左側施行例では34\%しか増加しなかっ たとしている12).

今回の症例で結紮切断を行ったのは左側内頸静脈で あった。したがって以下のように推測された。左側内頸 静脈の結紮により, 頭蓋内静脈圧の尣進がみられるとと もに脳圧が元進した。しかし術前に出血性ショック状態 のため, 利尿剤等による脳圧低下処置は不可能であった。 薬剂による処置が困難であったこともあり, 左側内頸静 脈の再建が必要とされた。片側内頸静脈の切除や結紮に より脳圧は立進するが，止血困難に陥ったことを考える と左側内頸静脈は優位側であったと考えられた。

近年の頭頸部外科の進歩により，頸部操作とともに頭 蓋底および頭盍内アプローチが必要な症例では，術前に 超音波検査や MRA 等で内頸静脈の形状やその大きさを 評価しておくことも必要ではないかと考えられた。

\section{まとめ}

1）内頸静脈の再建を要した虎咬傷例について報告し た。

2）本症例において, 左側内頸静脈が優位側と考学られ た。 


\section{参考文献}

1) Worrell L, Rowe $M$ and Petti G : Amaurosis; a complicatiom of bilateral radical neck dissection. Am J Otolaryngol 23:56 59, 2002.

2) Dulguerov $P$, Soulier C, Maurice J, et al. : Bilateral radical neck dissection with unilateral internal jugular vein reconstruction. Laryngoscope $108: 1692 \sim 1696,1998$.

3) De Vries WA, Balm AJ and Tiwari RM : Intracranial hypertension following neck dissection. J Laryngol Otol $100: 1427$ 1431, 1986.

4) Raj P, Moore PL, Henderson J, et al. : Bilateral cortical blindness; an usual complication following unilateral neck dissection. J laryngol Otol $116 ; 227 \sim 229,2002$.

5) Mahasin ZZ, Saleem $M$ and Gangopadhyay $K$ : Transverse sinus thrombosis and venous infarction of the brain following unilateral radical neck dissection. J Laryngol Otol $112: 88 \sim$ 91, 1998.

6）山崎信也, 川合宏仁, 田中一歩, 他 : 内頸静脈切除が硬膜 外腔圧に及ぼす影響. 蘇生 $19: 131 \sim 134,2000$.

7) Lichtenstein D, Saifi R, Augarde R, et al. : The internal jugular veins are asymmetric; usefulness of ultrasound before cather- ization. Intensive Care Med $27: 301 \sim$ 305, 2001.

8) Cormio M and Robertson CS : Ultrasound is a reliable method for determining jugular bulb dominance. J Neurosurg Anesthesiol $13: 250 \sim 254,2001$.

9) Di Chiro G, Fisher RL and Nelson $\mathrm{KB}$ : The jugular foramen. J Neurosurg $21: 447 \sim 460,1964$.

10) Navsa $\mathrm{N}$ and Kramer $\mathrm{B}: \mathrm{A}$ quantitative assessment of the jugular foramen. Anat Anaz $180: 269 \sim 273,1998$.

11) Durgun B, Ilgit ET, Cizmeli MO, et al. : Evaluation by angiography of the lateral dominance of the drainage of the dural venous sinuses. Surg Radiol Anat $15: 125 \sim$ 130, 1993.

12) Doepp F, Hoffmann O, Schreiber $S$, et al. : Venous collateral blood flow assessed by Doppler ultrasound after unilateral radical neck dissection. Ann Otol Rhinol Laryngol $110: 1055$ 1058,2001

原稿受付：平成15年12月22日 原稿採択：平成16年 2 月 4 日 別刷請求先 : 大島 収 厂070-8530 旭川市曙 1 条 1 丁目 旭川赤十字病院耳鼻咽喉科 